\section{Trehalose plus Chloramphenicol Prolong the Vase Life of Tulip Flowers}

\author{
Mari Iwaya-Inoue ${ }^{1}$ and Mutsumi Takata \\ Laboratory of Horticultural Sciences, Department of Plant Resources, Faculty \\ of Agriculture, Graduate School, Kyushu University, Ropponmatsu, Fukuoka \\ 810-8560, Japan \\ Additional index words. cell elongation, cut flowers, cycloheximide, senescence, tepal \\ wilting, Tulipa gesneriana, water content
}

\begin{abstract}
The tepals of cut tulips (Tulipa gesneriana L. cv. Ile de France) kept at $20^{\circ} \mathrm{C}$ had severely wilted 7 days after flower opening. Suppression of abscission and undesirable growth of tepals is required to extend vase life. Treatment with $50 \mathrm{~mm}$ trehalose in combination with $50 \mu_{\mathrm{M}}$ chloramphenicol (CAP) delayed abscission by 4 days compared with stems placed in distilled water or CAP without trehalose. Only $4 \%$ of trehalose+CAPtreated flowers exhibited tepal abscission 7 days after harvest, while $82 \%$ and $60 \%$ of flowers held in distilled water and CAP, respectively, did so; the tepals of trehalose+CAPtreated flower stems contained $50 \%$ more water than did those treated with CAP alone. Further, trehalose did not promote elongation of epidermal parenchyma cells in tepal tissues, but maintained radial enlargement of the cells. Thus, trehalose+CAP treatment is effective in prolonging vase life without abscission, water loss, or elongation of cells in tulip tepals, but slight wilting occurs in leaves.
\end{abstract}

Water stress limits vase life of cut flowers, and tulips have a very short vase life. Tepal senescence in tulips is considered to be ethylene-insensitive, without the accelerated wilting associated with climacteric ethylene production (Tirosh et al., 1983), as the application of exogenous ethylene to cut flowers has little effect (Woltering and van Doorn, 1988). Additionally, respiration decreases during tepal senescence of intact tulip flowers (Collier, 1997). Thus, treatment with silver thiosulfate (STS) does not prolong their vase life.

Suppressing abscission and undesirable growth is required to extend the vase life of

Received for publication 25 Apr. 2000. Accepted for publication 27 Nov. 2000. This work was supported in part by a Grant-in-Aid (No.11460016) for Scientific Research from the Ministry of Education, Science, Sports, and Culture of Japan to M.I.I. We thank Dr. M. Sakurai of the Tokyo Institute of Technology and Hayashibara Co., Ltd., for the gift of trehalose. The cost of publishing this paper was defrayed in part by the payment of page charges. Under postal regulations, this paper therefore must be hereby marked advertisement solely to indicate this fact. ${ }^{1}$ To whom reprint requests should be addressed. E-mail address: marircb@mbox.nc.kyushu-u.ac.jp tulip flowers. Cycloheximide (CHI), which inhibits protein synthesis, improved the vase life of the first florets of cut gladiolus spikes, although the opening and development of the fifth florets were severely inhibited (Otsubo and Iwaya-Inoue, 2000). Since tulips generally have only a single flower per stem and elongation of tepals and stems is undesirable, CHI prolongs vase life. A combination of germicides and sucrose is generally used to prolong the vase life of gladiolus (Gladiolus $\times$ grandiflora hort.), hybrid Limonium, Heuchera sanguinea Engelm., rose (Rosa), and freesia (Freesia) flowers (Bravdo et al. 1974; Doi and Reid, 1995; Han, 1998; Ichimura et al., 1999; Woodson, 1987). However, Jones and Hill (1993) reported that a bacteriocide, sodium dichloroisocyanuric acid (DICA), reduced longevity of tulip cv. Apeldoorn. To control bacteria, other kinds of treatments are needed, such as 8-hydroxyquinoline citrate (HQC) and 8-hydroxyquinoline sulfate (HQS) (van Doorn, 1997, 1998; van Doorn and Perik, 1990). However, because HQC, HQS, and $\mathrm{CHI}$ induce mutations, they are toxic to humans (Christner et al., 1999; Nsereko et al., 1998). Thus, more effective and safer treat- ments are needed. Chloramphenicol (CAP) also inhibits protein biosynthesis in prokaryotic cells and reduces bacterial growth (Hartke et al., 1998; Morato and Ribas, 1997). Although 2 to $5 \mathrm{~mm}$ CAP initiated apoptosis in dividing mammalian cells and is toxic to humans (Holt et al., 1997), intramuscular doses of $25 \mathrm{mg} \cdot \mathrm{kg}^{-1} \mathrm{CAP}$ could be used as a drug for treatment of severe infections in infants (Weber et al., 1999). In our study, $50 \mu \mathrm{M}$ CAP was used for prolonging vase life of cut tulip flowers. This concentration is slightly lower than that used by Weber et al. (1999), indicating that $50 \mu \mathrm{M}$ CAP is safe for humans.

Supplying sucrose promotes bud opening and retards flower senescence in many cut flowers (Bravdo et al., 1974; Doi and Reid, 1995; Han, 1998; Ichimura et al., 1999; Woodson, 1987). Recently, we demonstrated that trehalose, a nonreducing disaccharide consisting of two $\alpha$-[1, 1]-linked glucose units, markedy suppressed water loss and enhanced vase life and viability in petals of gladiolus, cv. Fujinoyuki, whereas other mono- and disaccharides and inhibitors had no effect (Otsubo and Iwaya-Inoue, 2000). Given that gladiolus petals, like tulip tepals, are generally ethyleneinsensitive (Woltering and van Doorn, 1988), trehalose may prevent water loss. In addition, trehalose is not toxic to humans and is currently being studied for use in processed foods and cosmetics because of its stability and chemical inertness. However, no studies have been reported utilizing trehalose together with other safer germicides for prolonging the vase life of cut flowers. Here we report on how trehalose and CAP affect the vase life of cut tulip flowers and discuss the role of trehalose in the senescence of the tepals and leaves.

\section{Materials and Methods}

Plant materials and treatments. About 200 tulip bulbs, cv. Ile de France, were grown in a laboratory and harvested from Feb. to Mar. 1999 at the early opening stage (Stage 1; Fig. 1 ), and used immediately. Tulip stems were recut under distilled water to a length of $25 \mathrm{~cm}$ and placed in test tubes containing $10 \mathrm{~mL}$ of distilled water or one of the test solutions [50 $\mu \mathrm{M}$ chloramphenicol (CAP), $50 \mathrm{~mm}$ trehalose, $50 \mathrm{~mm}$ trehalose with $50 \mu \mathrm{M}$ CAP, $100 \mathrm{~mm}$ trehalose with $50 \mu \mathrm{M}$ CAP or $100 \mu \mathrm{m}$ cycloheximide (CHI) with $50 \mu \mathrm{M}$ CAP]. All preparations were conducted in a room kept at $20 \pm$
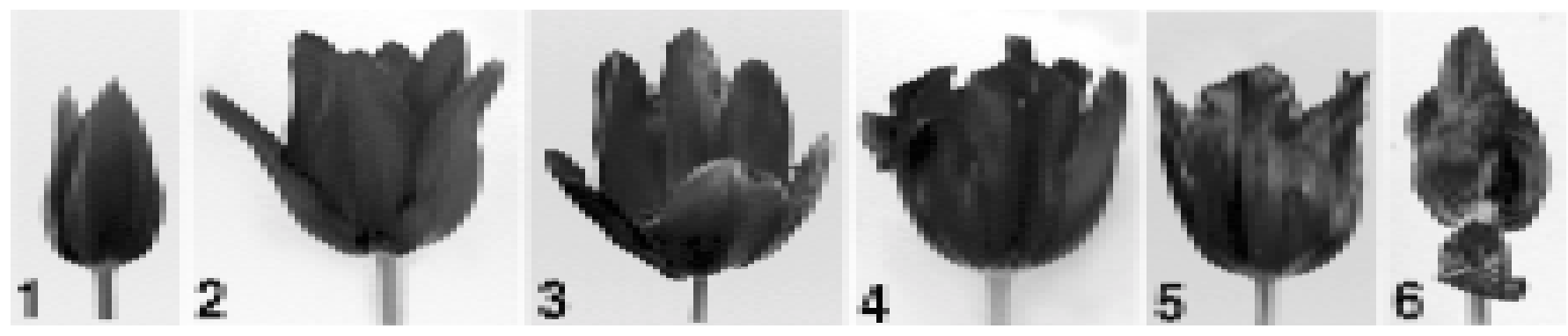

Fig. 1. Scores for tepal senescence in tulip (Tulipa gesneriana L. cv. Ile de France). The state of senescence for tepals was evaluated daily based on the degree of wilting and abscission. Life stages of the flower were defined by the following six scores: 1 , half-opened; 2 , fully opened; 3 , slightly wilted at the tepal edge; 4 , slightly wilted over half of tepal; 5 , wilted whole tepal; 6 , severely wilted and darkened whole tepal with abscission. 
$1{ }^{\circ} \mathrm{C}$ and $\approx 60 \%$ relative humidity, under $14 \mathrm{~h}$ of illumination at $100 \mu \mathrm{mol} \cdot \mathrm{m}^{-2} \cdot \mathrm{s}^{-1}$, and the flowers were evaluated daily.

Definition of vase life. The stage of senescence of tepals was evaluated daily based on the degree of wilting and abscission defined by the following six scores: 1 , half-opened; 2 , fully opened; 3 , slightly wilted at the edge; 4 , slightly wilted over half of the tepal; 5 , whole tepal wilted; 6 , whole tepal severely wilted, darkened, and abscised. The stage of senescence for leaves was also evaluated daily using the following five scores: 1 , no injury; 2 , slightly wilted at the edge; 3 , wilted over half

Table 1. Effects of trehalose, cycloheximide (CHI), and chloramphenicol (CAP) on percentage of tepal abscission in cut tulip flowers $7 \mathrm{~d}$ after treatment. ${ }^{\mathrm{z}}$

\begin{tabular}{|c|c|c|c|c|}
\hline \multirow[b]{2}{*}{ Treatment } & \multicolumn{3}{|c|}{ Trehalose (mM) } & \multirow{2}{*}{$\frac{\mathrm{CHI}(\mu \mathrm{M})}{100}$} \\
\hline & 0 & 50 & 100 & \\
\hline Distilled water & 81.8 & 12.5 & --- & --- \\
\hline $50 \mu \mathrm{M}$ CAP & 60.0 & 4.3 & $0^{y}$ & $0^{y}$ \\
\hline
\end{tabular}

${ }^{2}$ Abscission rates were averaged for $16-56$ cut flowers in each test solution.

${ }^{\text {y } T e p a l s ~ s e v e r e l y ~ i n j u r e d . ~}$ of the leaf; 4 , severely wilted with symptoms of chlorosis; 5 , entirely wilted with chlorosis. Wilting scores were averaged for 16 to 56 cut flowers in each test solution.

Measurement of water content. Fresh weights of tepals and leaves of the cut tulip flowers were measured $0,1,3,5$, and $7 \mathrm{~d}$ after harvest. Dry weights were obtained after drying tissues in an oven at $90{ }^{\circ} \mathrm{C}$ for $20 \mathrm{~h}$. Water content per plant $(\mathrm{g})$ was expressed as the difference between fresh and dry weight, and water content per unit dry weight was calculated ( $g \cdot \mathrm{g}^{-1}$ dry weight). Data were obtained for nine cut flowers each day.

Measurement of cell size. Tepal tissues from cut flowers were fixed in 5 formalin: 5 acetic acid: 90 80\% ethanol (FAA) (by volume). Epidermal cells from the upper part of tepal tissues were subjected to microscopic observations (Axiphot, Carl Zeiss Co., Ltd., Tokyo), and cell sizes were determined for both parenchyma and guard cells. Mean cell length and width were recorded for nine files of cells in three different sections from three individual flowers.
Results

Effects of trehalose and protein biosynthesis inhibitors on vase-life. The tulip flower consists of three outer tepals and three inner ones (Fig. 1). The flower bud (Stage 1) opened $1 \mathrm{~d}$ after harvest (Stage 2). At $7 \mathrm{~d}$ after harvest, tepal abscission in trehalose+CAP-treated flowers was $4 \%$, vs. $82 \%$ and $60 \%$, respectively, in distilled water and CAP-treated flowers (Table 1). Flowers treated with water or CAP alone received a score of over 5 at $7 \mathrm{~d}$ (Fig. 2A). On the other hand, $100 \mu \mathrm{M} \mathrm{CHI} \mathrm{plus}$ CAP inhibited tepal abscission entirely (Table 1 ), but the uppermost internode (above the leaves) was severely wilted and the flower head drooped. Thus, CHI is not useful for prolonging the vase life of tulips.

We next studied the effects of combinations of trehalose and CAP on flower senescence. Flowers treated with $50 \mathrm{~mm}$ trehalose plus CAP had the lowest abscission rate; thus, trehalose was clearly more effective than CAP alone. Flowers treated with trehalose+CAP required $12 \mathrm{~d}$ to reach the abscission stage (score of 6 ) vs. $8 \mathrm{~d}$ for the controls (Fig. 2A) - a 4-d delay
Tepals

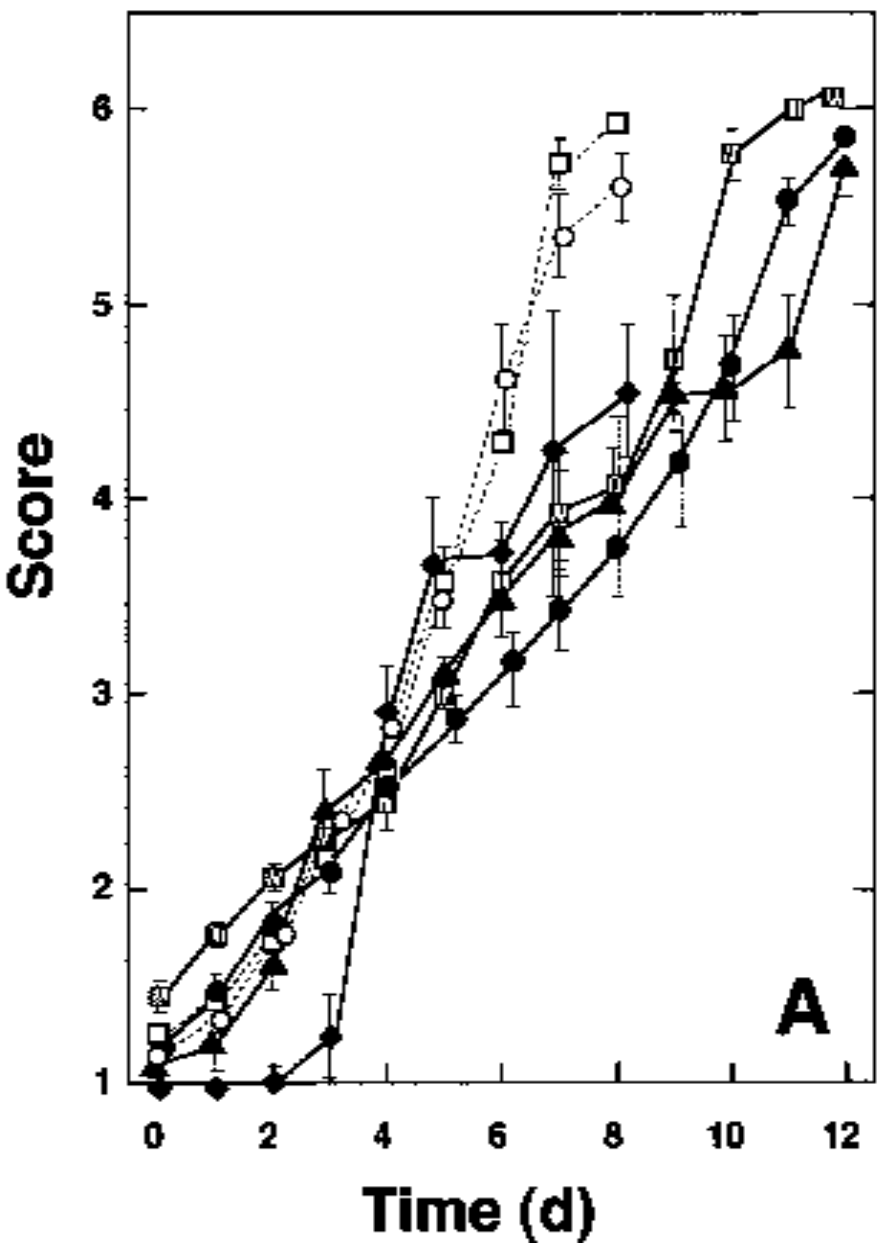

Leaves

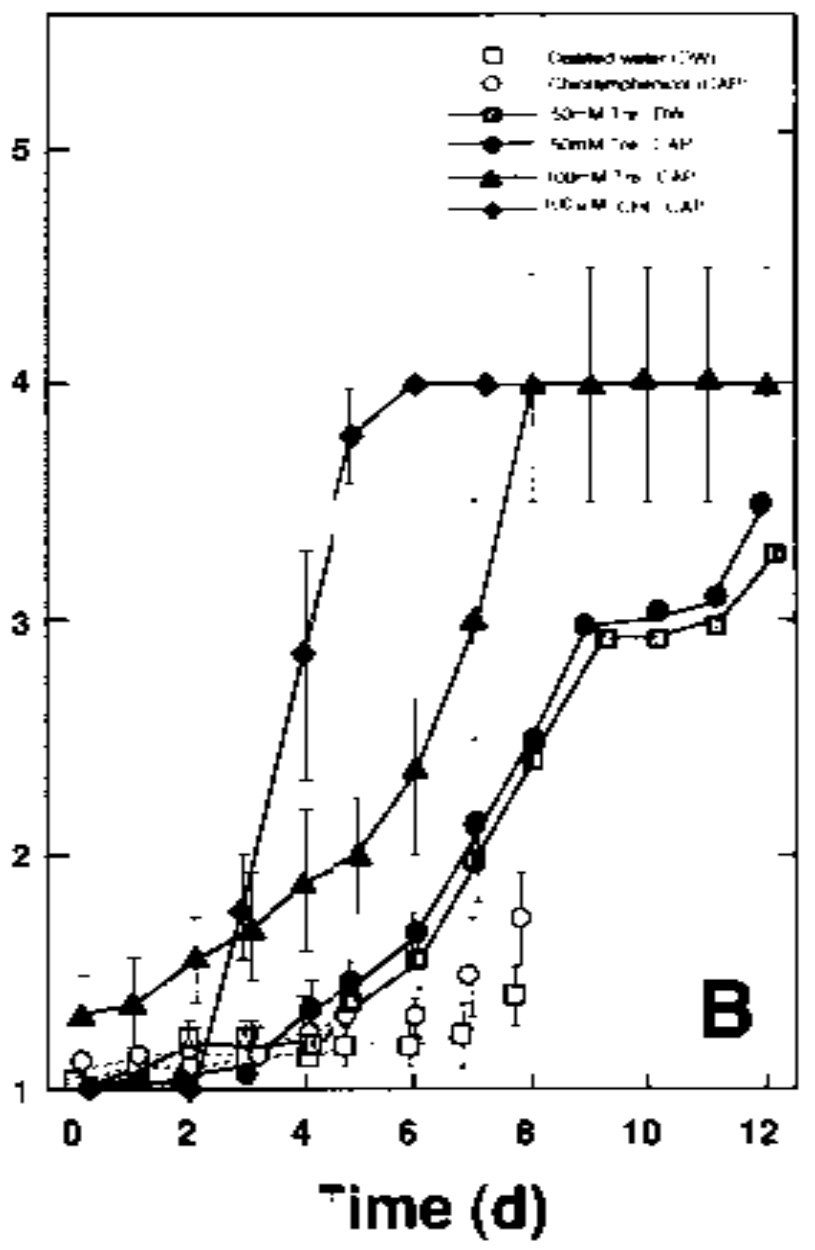

Fig. 2. Effects of trehalose and protein inhibitors on wilting of (A) tepals and (B) leaves of cut tulip flowers. Flower wilting was scored as shown in Fig. 1. Life stages of leaves were defined by the following four scores: 1 , no injury; 2 , slightly wilted at the leaf edge; 3 , wilted over half of leaf; 4 , severely wilted with symptoms of chlorosis; 5 , entirely wilted with chlorosis. Cut flowers were kept in distilled water ( $\square), 50 \mu \mathrm{M}$ chloramphenicol (CAP) (O), $50 \mathrm{~mm}$ trehalose with distilled water (马), 50mm trehalose with $\mathrm{CAP}(\bullet), 100 \mathrm{~mm}$ trehalose with $\mathrm{CAP}(\boldsymbol{\Delta}), 100 \mu \mathrm{m}$ cycloheximide $(\mathrm{CHI})$ with $\mathrm{CAP}(\bullet)$. Symbols represent mean $\pm \mathrm{se}$ $(\mathrm{n}=16 \sim 56)$. SE bars are not visible when they are smaller than symbols. 
relative to treatment with CAP alone. In addition, although tepal abscission was entirely suppressed by $100 \mathrm{~mm}$ trehalose plus CAP (Table 1), the tepals turned dark (data not shown). Wilting was suppressed more by 50 mu trehalose than by $100 \mathrm{~mm}$ trehalose plus CAP. The $50 \mathrm{~mm}$ trehalose treatments were the most effective for delaying senescence.

In the leaves, clear effects were not observed with the CAP treatment (Fig. 2B). Leaves treated with $\mathrm{CHI}$ began to wilt at $3 \mathrm{~d}$ and had suffered severe damage by $5 \mathrm{~d}$. The $100 \mathrm{~mm}$ trehalose treatments caused more leaf wilting and chlorosis than did the $50 \mathrm{~mm}$ treatments. Thus, CAP did not substantially affect leaf senescence, while trehalose, particularly at higher concentrations, accelerated leaf wilting and chlorosis. Based on these results, a solution containing $50 \mathrm{~mm}$ trehalose $+50 \mu \mathrm{M}$ CAP is recommended, although $50 \mathrm{~mm}$ trehalose alone is also commercially useful.

Water content and dry weight of tepals and leaves after treatment with trehalose and CAP. In order to evaluate wilting quantitatively, water content and dry matter per plant, and water content per dry matter of tepals and leaves, respectively, were determined (Fig. 3). Tepal water content following treatment with $50 \mathrm{~mm}$ trehalose plus $50 \mu \mathrm{M}$ CAP (hereafter called the trehalose+CAP-treated) was about twice that following treatment with $50 \mu \mathrm{m}$ CAP (hereafter called the control) at $7 \mathrm{~d}$ (Fig. $3 \mathrm{~A})$. Dry weights of the tepals gradually increased in trehalose+CAP-treated flowers until $5 \mathrm{~d}$ after harvest while it decreased in the controls after $3 \mathrm{~d}$ (Fig. 3B). As a result, water content per gram dry weight was maintained at $90 \%$ of the initial value in trehalose+CAPtreated flowers at $7 \mathrm{~d}$ after harvest (Fig. 3C). On the other hand, water content of tepals treated only with CAP had decreased markedly.

Leaf water content per dry weight in trehalose+CAP-treated stems retained its initial value while that in the controls slightly increased for the same duration (Fig. 3F), because dry weight decreased more in the control tissues (Fig. 3E) while water content per plant maintained the initial values in both treatments at $7 \mathrm{~d}$ after harvest (Fig. 3D). These results suggest that trehalose-treated tepals specifically maintained high water content, with little effect on leaves.

Epidermal cell growth after treatment with trehalose and CAP. Tulip tepals grew and their appearance became undesirable, even after they were cut and placed in a vase. The elongation of the parenchyma cells of the epidermal tissues in trehalose+CAP-treated flowers increased gradually for $7 \mathrm{~d}$ after harvest, while that of the guard cells had increased slightly at $7 \mathrm{~d}$ (Fig. 4A). The growth curves of cell length in both types of cells treated with trehalose plus CAP were the same as those of the controls. Since the length of intact tepals had increased by $30 \%$ to $40 \% 7 \mathrm{~d}$ after treatment and tepal growth essentially paralleled parenchyma cell elongation, cell elongation was responsible for this growth. In contrast, trehalose affected radial enlargement; it maintained parenchyma cell width until $7 \mathrm{~d}$, while the control cells decreased in size beginning $3 \mathrm{~d}$ after treatment (Fig. 4B). Thus, trehalose+CAP did not affect cell elongation but maintained epidermal cell width compared with controls treated with CAP alone.
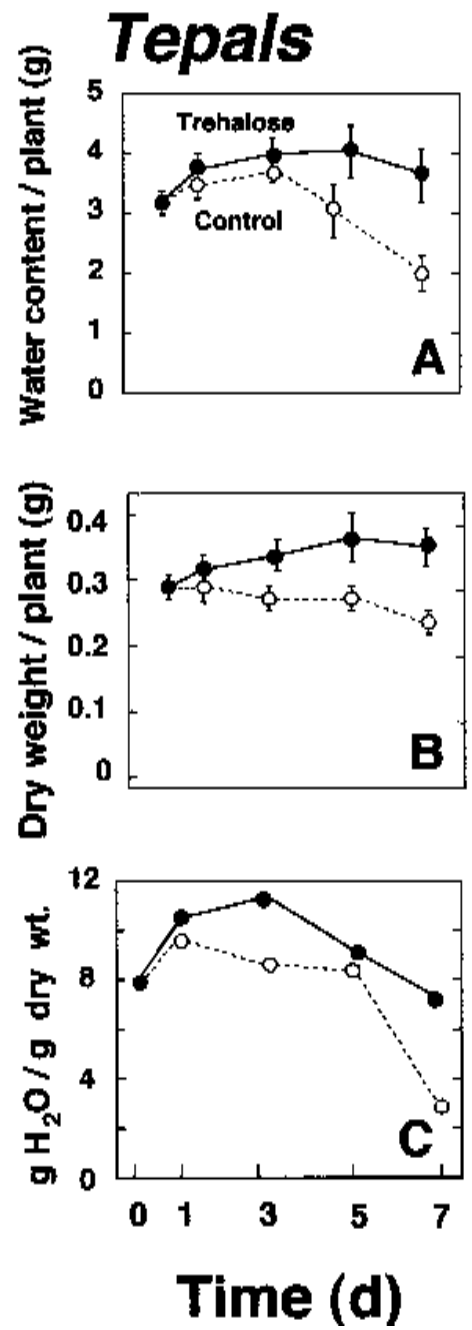

Fig. 3. Effects of trehalose + CAP treatment on $(\mathbf{A}$ and $\mathbf{D})$ water content per plant $(\mathrm{g}),(\mathbf{B}$ and $\mathbf{E})$ dry matter per plant (g), and $(\mathbf{C}$ and $\mathbf{F})$ rate of water content per dry matter in $(\mathbf{A}, \mathbf{B}$, and $\mathbf{C})$ tepals and $(\mathbf{D}, \mathbf{E}$, and $\mathbf{F})$ leaves. Trehalose+CAP treatment $(\mathbf{O})$ indicates $50 \mathrm{~mm}$ trehalose with $50 \mu \mathrm{M}$ CAP, and control $(\mathrm{O})$ is $50 \mu \mathrm{M}$ CAP. Symbols represent mean \pm SE $(n=8 \sim 14)$. SE bars are not visible when they are smaller than symbols.

\section{Leaves}
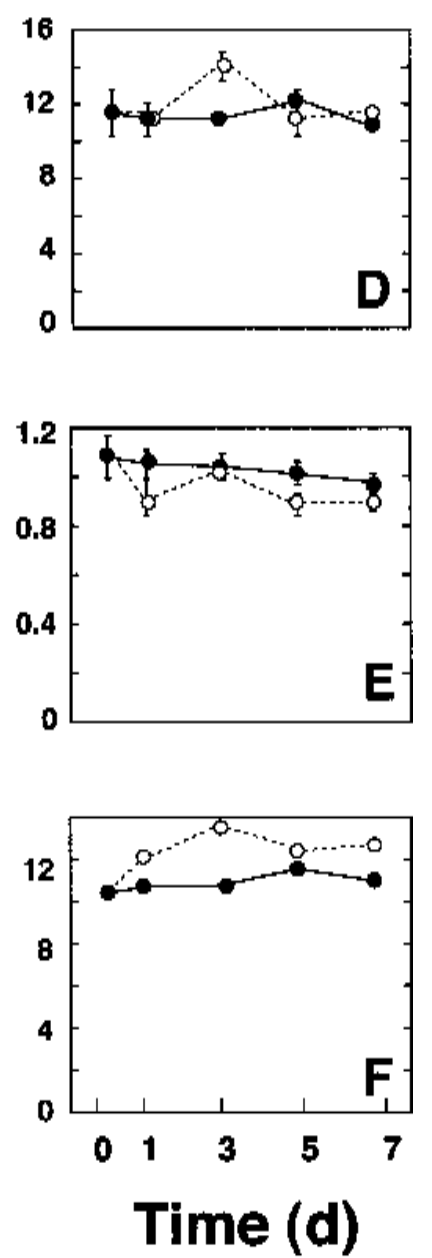

\section{Discussion}

A treatment for delaying senescence in cut tulip flowers. Tepal wilting progressed gradually in cut 'Ile de France' tulip flowers in distilled water (Fig. 1). Treatment with $50 \mu \mathrm{m}$
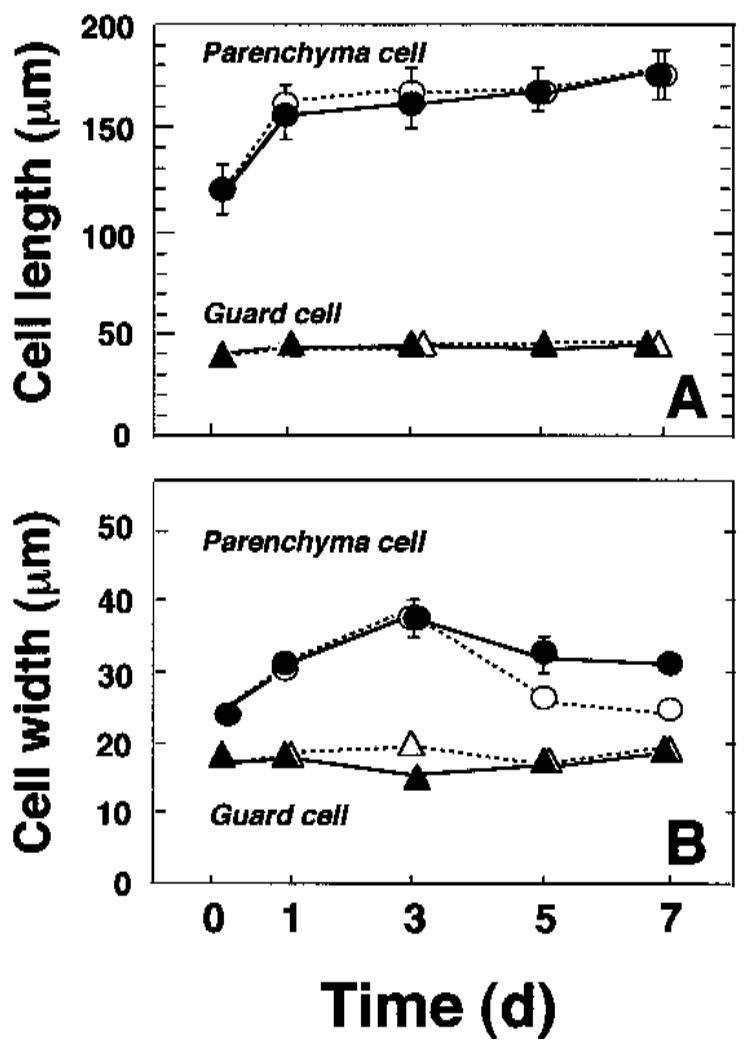

Fig. 4. Effects of trehalose on (A) cell length of parenchyma cells and guard cells, and (B) cell width of these cells in the epidermis of tulip tepal tissues. Closed symbols indicate cell size of parenchyma cells $(\boldsymbol{O})$ and guard cells $(\boldsymbol{\Delta})$ treated with $50 \mathrm{~mm}$ trehalose plus $50 \mu \mathrm{m}$ CAP. Open symbols indicate cell size of parenchyma cells $(O)$ and guard cells $(\Delta)$ treated with $50 \mu \mathrm{M}$ CAP (control). Symbols represent mean \pm SE $(n=9)$. SE bars are not visible when they are smaller than symbols. 
$\mathrm{CAP}$, an inhibitor of protein biosynthesis in prokaryotic cells, delayed tepal abscission (Table 1). Disinfectants such as CAP and HQC improve water conductance by preventing bacterial growth (Hartke et al., 1998; van Doorn et al., 1990, 1998). Treatment with 100 $\mu_{\mathrm{M}} \mathrm{CHI}$, an inhibitor of protein biosynthesis in eukaryotic cells, inhibited tepal abscission and delayed tepal wilting (Table 1 and Fig. 2A), but it injured the tepals as well as the stem and leaves (data not shown). Treatment of cultivars such as 'Apeldoorn', 'Don Quichotte', and 'White Dream' with $1 \mathrm{~mm}$ CHI prevented flower opening and hastened loss of color, while the stems failed to elongate or respond to light, resulting in a shorter vase life (Jones et al., 1994). Although even a 10-fold dilution suppressed tepal abscission (Table 1), it did not prolong the commercially useful longevity of the tulip flowers.

On the other hand, treatments with $50 \mathrm{~mm}$ trehalose plus CAP were more effective in maintaining quality of tulip tepals and leaves; $100 \mathrm{~mm}$ trehalose + CAP caused color change and a higher ratio of leaf wilting and chlorosis (Fig. 2). Very recently, we found that $100 \mathrm{~mm}$ trehalose was the best concentration for delaying the senescence of cut gladiolus spikes (Otsubo and Iwaya-Inoue, 2000). These results indicate that a suitable concentration of trehalose must be determined for each species.

Effects of trehalose on water retention in tepals and leaves. Based on the finding that the tepals of flowers treated with $50 \mathrm{~mm}$ trehalose plus $50 \mu \mathrm{M}$ CAP had much higher water retention than did the controls at $7 \mathrm{~d}$, we conclude that trehalose may play an important role in preventing water loss in cut tulip flowers (Fig. 3A). Survival phenomena under environmental stresses, such as desiccation and freezing, may be related to the presence of trehalose in the cells of bacteria, yeast, fungi, algae, and insects (Crowe et al., 1984; Elbein, 1974; Hottinger et al., 1994; Lee et al., 1989; Müller et al., 1995; Sano et al., 1999). However, tepal water contents were $\approx 90 \%$ of the fresh weight; thus, the function of trehalose in retaining water differs from that in anhydrobiotic organisms. In general, higher plants, except for a few drought-resistant plants such as Myrothamnus flabellifolius Welw. (Bianchi et al., 1993; Drennan et al., 1993) and Selaginella lepidophylla Hook. and Grev. Spring. (Zentella et al., 1999), do not accumulate high concentrations of trehalose. Holmström et al. (1996) concluded that tolerance to water stress was not induced by osmotic adjustment with trehalose in transgenic tobacco (Nicotiana tabacum L.) plants because the trehalose concentrations seemed too low for osmotic adjustment, i.e., $\leq 5 \mathrm{~mm}$ in the cytosol. Although trehalose accumulation was very low in trehalose-treated gladiolus petals (unpublished data), trehalose increased water retention more than did any of the other sugars examined, including sucrose, maltose, fructose, and glucose (Otsubo and Iwaya-Inoue, 2000). In contrast, a major effect of sucrose on cut gladiolus spikes was probably to increase the osmotic concentration of the florets and leaves, and, in so doing, to improve water uptake (Bravdo et al., 1974).
On the other hand, leaf water content per gram dry weight for trehalose+CAP-treated flowers did not change, while that for the controls increased slightly (Fig. 3F). In addition, the trehalose+CAP-treated leaves appeared to be more injured and wilted than did the controls over the course of the $7 \mathrm{~d}$ (Fig. 2 B). A similar tendency was observed in gladiolus bracts (Otsubo and Iwaya-Inoue, 2000). Although water loss in tulip leaves has only a slight influence on the appearance of the cut flowers, further study is necessary to investigate leaf injuries in trehalose-treated cut flowers. Recent studies indicate that a low level of trehalose in most higher plants could be the result of hydrolysis by trehalase (Goddijn and Smeekens, 1998; Goddijn et al., 1997; Müller et al., 1995). These results suggest that an excessive accumulation of trehalose is toxic to plant tissues.

Role of trehalose in cell elongation and enlargement in tepals. Fifty millimolars of $(\approx 1.7 \%)$ trehalose did not specifically enhance elongation in either parenchyma or guard cells in tepal tissues (Fig. 4A). Despite their undesirable appearance, tulip tepals and stems grew well even in a vase; thus, the trehalose treatment is useful for cut tulip flowers. The growth of tissue-cultured soybean [Glycine max (L.) Merr.] embryos was retarded more on media containing 3\% trehalose than on those containing 3\% sucrose (Ikeda et al., 2000). Trehalose also suppressed growth and cell wall synthesis in vitro of shoot tips of Cuscuta reflexa Roxb. (Veluthambi et al., 1982). On the contrary, flower diameter and fresh weight of cut roses were markedly increased by $3 \%$ sucrose in combination with HQS (Ichimura et al., 1999). Additionally, a vase solution containing $2 \%$ sucrose and Physan $20^{\circledR}$, a quaternary ammonium disinfectant [commercial mixture consisting of $10 \% n$-alkyl $\left(\mathrm{C}_{12}-\mathrm{C}_{14}\right)$ dimethylethylbenzyl ammonium chlorides], promoted bud opening and prolonged the longevity of individual florets of hybrid Limonium (Doi and Reid, 1995). These results suggest that sucrose supplied the energy and carbon skeletons required for bud opening, whereas trehalose may not act as an energy source as sucrose does.

In conclusion, trehalose played an important role in prolonging tulip vase life, although its mechanism of action remains unknown. Additionally, Marousky (1972) reported that sucrose and HQC improved flower opening, longevity, and increased turgidity in Gypsophila. The fact that maintenance of parenchyma cell enlargement was observed only in trehalose+CAP-treated tulip flowers suggests that trehalose also maintained turgor in tepals (Fig. 4B). Further, trehalose suppressed ion leakage in gladiolus petals (Iwaya-Inoue et al., 1999). Bakaltcheva et al. (1994) suggested that trehalose protects biological membranes under drought stress. Maintenance of membrane integrity would help cells maintain turgor, resulting in reduced water loss in tulip tepals and gladiolus petals. In order to clarify this mechanism of cut flower senescence, further studies of tissue viability, turgor pressure, and water status are under way.

\section{Literature Cited}

Bakaltcheva, I., W. Williams, J. Schmitt, and D. Hincha. 1994. The solute permeability of thylakoid membranes is reduced by low concentrations of trehalose as a cosolute. Biochem. Biophys. Acta 1189:38-44.

Bianchi, G., A. Gamba, R. Limiroli, N. Pozzi, R. Elster, F. Salamini, and D. Bartels. 1993. The unusual sugar composition in leaves of the resurrection plant Myrothamnus flabellifolia. Physiol. Plant. 87:223-226.

Bravdo, B., S. Mayak, and Y. Gravrieli. 1974. Sucrose and water uptake from concentrated sucrose solution by gladiolus shoots and effect of these treatments on floret life. Can. J. Bot. 52:1271-1281.

Christner, C., R. Wyrwa, S. Marsch, G. Kullertz, R. Thiericke, S. Grabley, D. Schumann, and G. Fischer. 1999. Synthesis and cytotoxic evaluation of cycloheximide derivatives as potential inhibitors of FKBDP12 with neuroregenerative properties. J. Med. Chem. 42:3615-3622.

Collier, D.E. 1997. Changes in respiration, protein and carbohydrates of tulip tepals and Alstromeria petals during development. J. Plant Physiol. 150:446-451.

Crowe, J., L. Crowe, and D. Chapman. 1984. Preservation of membranes in anhydrobiotic organisms: The role of trehalose. Science 223:209217

Doi, M. and M.S. Reid. 1995. Sucrose improves the postharvest life of cut flowers of a hybrid Limonium. HortScience 30:1058-1060.

Drennan, P.M., M.T. Smith, D. Goldsworthy, and J. van Staden. 1993. The occurrence of trehalose in the leaves of the desiccation-tolerant angiosperm Myrothamnus flabellifolius Welw. J. Plant Physiol. 142:493-496.

Elbein, A. 1974. The metabolism of $\alpha, \alpha$-trehalose. Adv. Carbohydrate Chem. Biochem. 30:227256

Goddijn, O. and S. Smeekens. 1998. Sensing trehalose biosynthesis in plants. Plant J. 14:143-146.

Goddijn, O.J.M., T.C. Verwoerd, E. Voogd, R.W.H.H. Krutwagen, P.T.H.M. de Graaf, J. Poels, K. van Dun, A.S. Ponstein, B. Damm, and J. Pen. 1997. Inhibition of trehalase activity enhances trehalose accumulation in transgenic plants. Plant Physiol. 113:181-190.

Han, S.S. 1998. Postharvest handling of cut Heuchera sanguine Engelm. Flowers: Effects of sucrose and silver thiosulfate. Hortscience 33:731-733.

Hartke A., J.C. Giard, J.M. Laplace, and Y. Auffray. 1998. Survival of Enterococcus faecalis in an oligotrophic microcosm-Changes in morphology, development of general stress resistance, and analysis of protein synthesis. Appl. Environ. Microbiol. 64:4238-4245.

Holmström, K.O., E. Mäntylä, B. Welin, A. Mandel, E.T.Palva, O.E. Tunnela, and J.Londesborough. 1996. Drought tolerance in tobacco. Nature 379:683-684

Holt D.E., T.A. Ryder, A. Fairbairn, R. Hurley, and D. Harvey. 1997. The myelotoxicity of chloramphenicol-In vitro and in vivo studies. I. In vitro effects on cells in culture. Human Expt. Toxicol. 16:570-576.

Hottinger, T., C. De Virgilio, M. Hall, T. Boller, and A. Wiemken. 1994. The role of trehalose synthesis for the acquisition of thermo-tolerance in yeast. II. Physiological concentration of trehalose increases the thermal stability of proteins in vitro. Eur. J. Biochem. 219:187-193.

Ichimura, K., K. Kojima, and R. Goto. 1999. Effects of temperature, 8-hydroxyquinoline sulphate and sucrose on the vase life of cut rose flowers. Postharv. Biol. Technol. 15:33-40.

Ikeda, T., M. Iwaya-Inoue, T. Fukuyama, and H. 
Nonami. 2000. Trehalose changes hydraulic conductance of tissue-cultured soybean embryos. Plant Biotechnol. 17:119-125.

Iwaya-Inoue, M., M. Otsubo, and G. Watanabe. 1999. Cellular water status in flower petals during senescence. Cryobiol. Cryotech. 45:5157.

Jones, R.B. and M. Hill. 1993. The effect of germicides on the longevity of cut flowers. J. Amer. Soc. Hort. Sci. 118:350-354.

Jones, R.B., M. Serek, C.-L. Kuo, and M.S. Reid. 1994. The effect of protein synthesis inhibition on petal senescence in cut bulb flowers. J. Amer. Soc. Hort. Sci. 119:1243-1247.

Lee, C.W.B., S.K. Das Gupta, J. Mattai, G.G. Shipley, O.H. A-Mageed, A. Makriyannis, and R.G. Griffin. 1989. Characterization of the $L_{\lambda}$ phase in trehalose-stabilized dry membranes by solidstate NMR and X-ray diffraction. Biochemistry 28:5000-5009.

Marousky, F.J. 1972. Influence of storage temperature, handling and floral preservatives on postharvest quality of Gypsophyla. Proc. Florida State Hort. Sci. 85:419-422.

Morato, M.J. and F. Ribas. 1997. Resistance to chlorine of freshwater bacterial strains. J. Appl. Microbiol. 821:7-18.
Müller, J., T. Boller, and A. Wiemken. 1995. Trehalose and trehalase in plants: Recent developments. Plant Sci. 112:1-9.

Nsereko, V.L., J.A. Rooke, C.J. Newbold, and R. J. Wallace. 1998. Influence of protease inhibitors on nitrogen distribution in ensiled perennial ryegrass and the utilisation of silage nitrogen for growth by rumen bacteria in vitro. Animal Feed Sci. Tech. 76:51-63.

Otsubo, M. and M. Iwaya-Inoue. 2000. Trehalose delays senescence in cut gladiolus spikes. HortScience 35:1107-1110.

Sano, F., N. Asakawa, Y. Inoue, and M. Sakurai. 1999. A dual role for intracellular trehalose in the resistance of yeast cells to water stress. Cryobiology 39:80-87.

Tirosh, T., S. Mayak, and A.H. Halevy. 1983. Interrelated effects of short-term treatment with nutritive solution and shipment conditions on the equality of iris flowers. Scientia Hort. 19:161166.

van Doorn, W.G. 1997. Water relations of cut flowers. Hort. Rev. 8:1-85.

van Doorn, W.G. 1998. Effects of daffodil flowers on the water relations and vase life of roses and tulips. J. Amer. Soc. Hort. Sci. 123:146-149.

van Doorn, W.G., and R.R.J. Perik. 1990. Hydroxy- quinoline citrate and low $\mathrm{pH}$ prevent vascular blockage in stems of cut rose flowers by reducing the number of bacteria. J. Amer. Soc. Hort. Sci. 115:979-981.

Veluthambi, K., S. Mahadevan, and R. Maheshwari. 1982. Trehalose toxicity in Cuscuta reflexa. Plant Physiol. 70:686-688.

Weber, M.W., S.R. Gatchalian, O. Ogunlesi, A. Smith, G.H. McCracken, S. Qazi, A.F. Weber, K. Olsen, and E.K. Mulholland. 1999. Chloramphenicol pharmacokinetics in infants less than three months of age in the Philippines and the Gambia. Pediatric Infect. Dis. J. 18:896-901.

Woodson, W.R. 1987. Postharvest handling of budcut freesia flowers. HortScience 22:456-458.

Woltering, E.J. and W.G. van Doorn. 1988. Role of ethylene in senescence of petal morphological and taxonomical relationships. J. Expt. Bot. 39:1605-1616.

Zentella, R., J.O. Mascorro-Gallardo, P. van Dijck, J. Folch-Mallol, B. Bonini, C. van Vaeck, R. Gaxiola, A.A. Covarrubias, J. Nieto-Sotelo, J.M. Thevelein, and G. Iturriaga. 1999. A Selaginella lepidophylla trehalose-6-phosphate synthase complements growth and stress-tolerance defects in a yeast tps 1 mutant. Plant Physiol. 119:1473-1482. 